\title{
Domestic Violence in Province 3: An Empirical Reference to Case of Women IN Pharping, Kathmandu
}

\author{
Muna Poudel, LLM \\ Advocate, Corporate Law Practitioner \\ poudelmuna18@gmail.com
}

\begin{abstract}
The aim of the research is to explore the domestic violence in woman of Pharping, Kathmandu. The descriptive and exploratory research designs have been adopted in the study. The sample has been taken from Sheshnarayan Mahila Bidhyalaya, Pharping, Kathmandu. The study has been focused only on women. The purposive sampling method has been used to collect the information. The descriptive analysis concluded that women in city are still victims of discrimination and domestic violence. There is a great need for the commitment of all people including social workers, organizations, and political institutions to bring an end to all forms of violence against woman.
\end{abstract}

Keywords; Domestic Violence, Discriminations, Physical Violence, Economical Violence, Mental Violence, Social Violence

\section{Introduction}

Domestic violence is one of the violent acts, which inflict pain and harm to the woman. Violence may be in different places and different areas. Nowadays, domestic violence is one of the severe problems in the society. Mainly the victims are woman. In different part of the world, the discrimination against women is taken as very serious problem. Nepal is not an exception. In theory, men and women are said to be complement of each other. But in fact, it is a lopsided relationship with the woman performing the roles of protectors, nurturer, healer and guide. Nepali woman are daughters, wives and mothers, but are not recognized as individuals with their own identity, despite the fact that they are as human as men. Society has relegated women to the lowest rank and to a submissive role, confined to the home and farm and their responsibilities there due to their maternal function. They are discouraged and prevented from taking part in public life. In Nepal there are different laws against domestic violence. A separate act is made 
in order to protect woman from violence. Even the constitution itself provides guarantee for the protection of woman, but still woman are the victims of domestic violence. For individuals all over the world, home is a safe heaven. Yet it is at home that many people, all over the world are subjected to heinous crimes of suffering, terror and violence and even death at the hands of family members who are supposed to love, care and protect them. They are victimized physically, sexually, emotionally, and psychologically. However, when the abuse is inside the home, it is condoned by a large part of the society, state and law enforcement machinery.

\section{Research Objective}

To know the situation of domestic violence in women with reference to Sheshnaraya Mahila Bidhyalaya, Pharping, Kathmandu.

\section{Literature Review}

The term domestic violence is commonly used to describe the abuse suffered at the hands of a partner. Violence means any kind of abusive behavior. Domestic violence means the violence that occurs within the family. The united Nation gives the most comprehensive definition of family violence. Accordingly, violence in the family manifests itself as physical mistreatment, often repetitive, which is interrelated to the exercise of mental torture, neglect of basic needs and sexual molestation. Violence is generally exercised in the closest family unit where there are dependency relationships, and results in grave injury to the victims; repetitive violence may be distinguished from the occasional occurrence of violence (Revathi, 2004). Violence against someone carries the elements of crime, i.e. harm brought about by the human conduct, which state desires to prevent through different nodes and fixes certain procedures and methods to address it. Therefore, violence of any kinds against anyone is a crime (Pradhananga and Shrestha, 2002).

According to the protection of women from domestic violence Act,2005, for the purpose of this act, any act, omission or commission or conduct of the respondent shall constitute domestic violence in case it-Harms or injuries or endangers the health, safety, life, limb or well being, whether mental or physical, of the aggrieved person do or tends to do so and includes causing physical abuse, sexual abuse, verbal and emotional abuse and economic abuse, or Harasses, harms, injures, or endangers the aggrieved person with a view to coerce her or any other person related to her to meet any unlawful demand for any dowry or other property or valuable security: or Has the effect of threatening the aggrieved person or any person related to her by any conduct mentioned in clause (a) and (b): or Otherwise, injuries or causes harm, whether physical or mental, to the aggrieved person (Protection of Women Violence Act, 2005). According to the domestic violence (prevention) Bill drafted by the lawyers collective in new Delhi, domestic violence meansany action or behavior that harms or injures or has the potential of harming or injuring the health, the safety or well-being of the person aggrieved or any child in the care of the person aggrieved or in her environment and includes but is not limited to.

- Physical abuse or threat of physical abuse.

- Sexual abuse or a threat of sexual abuse.

- Emotional, verbal and psychological abuse. 
- Intimidation

- Harassment

- Damage to or destruction of property.

- Taking or attempting to take or appropriate belonging to the person aggrieved or jointly owned by the respondent ad the aggrieved party without her consent.

- Demands for dowry, oral or written in any manner from the person aggrieved or any of her relatives.

- Any conduct which is of such a nature as to cause in the mind of the person aggrieved a reasonable apprehension that it will be harmful or causing mental disorder for her or injuries for her to live with the respondent and the person aggrieved may not be reasonably expected to live with respondent (Revanthi, 2002).

\section{Nature of Domestic Violence Against Women}

The domestic violence has distinct character as opposed to other types of violent crime. It can be characterized by at least five features:

- It is perpetuated by someone close to the victim, usually her partner or ex-partner;

- It happens in intimate settings which are presumed by society to be sites of support and care;

- It is a recurring form of abuse generally characterized by a cycle of violence: the abuse is followed by a period of respite after which tensions build up again and eventually explode into another violent episode;

- The abuser uses domestic violence to control and coerce the victim; and

- The abuse has profound emotional and psychological effects on the victim, who often believes (and is often told by the abuser) that she is to blame for the violence.

\section{Classification of Domestic Violence Against Women}

In simple words, domestic violence against women can be defined as any kinds of gender based violence that occurs within the domain of house. As mentioned below, it may be of categorized into five types (UNICEF, 2001).

\section{Physical abuse}

Abuse committed with an objective of giving pain is known as physical abuse. This includes slapping, beating, arm-twisting, and stabbing, strangling, burning, choking, kicking, threats with a weapon, murder, traditional harmful practices like female genital mutilation and widowhood abuse.

\section{Sexual abuse}

Those abuse which occurs due to women's incompetence (may be due to unwillingness or any other reasons) in fulfilling the sexual desires of men. This includes coerced sex through threats, intimidation or physical force, forced prostitution, or any unwanted sexual act.

\section{Psychological abuse}

The psychological abuse includes all intimidating and threatening behavior, 
persecution, abandonment or threats of abandonment, confinement, surveillance, verbal abuse, and mental torture.

\section{Emotional abuse}

Emotional abuse emotional abuse includes causing fear, shame, public embarrassment, continued threats and taunts, isolation and humiliation. Economic abuses includes acts such as denial of funds, exploitation, controlling access to healthcare, food, basic necessities and denial of rightful income.

Some other forms of violence are as follows:

\section{Social violence}

This violence includes the violence like demeaning, disparaging, belittling, defamatory statements, virginity trap etc.

\section{Intellectual violence}

Such type of violence includes the violence like non submission of oneself for confrontation, discussion even in pressing issues.

\section{Violence of Woman at Conjugal Home (Husband's Home)}

Conjugal home is the home of the husband. In our patriarchal society there is a trend that after the marriage the girl would go to the husband's house. Marriage in every society is a bond which in the present society is based on companionship. In Indian society, however the woman enters her conjugal home with certain values and convictions of her own. But, soon she is expected to shift her loyalties from parents and siblings to husband and in-laws. After her marriage she has no independent social or economic status in the family. Similar is the situation in Nepal. Whenever the family runs into problems, such problems are generally alleged as caused by one single member-the wife, even though the family consists of a number of individuals. For all marital problems, it is the wife who is criticized for maladjustment. The power relations between spouses and their families are indispensible related to dowry and ramifications. In India, there is a tendency that marital violence is under overall heads of dowry harassment and dowry deaths. So dowry is one of the major factors responsible for domestic violence. Dowry is inseparably interlinked with the general status of women in our society.

Wife beating is the most common form of abuse throughout the globe irrespective of class, caste, religion etc. The women's organization in Delhi analyses that wife beating is the common among social classes as it is a reflection of the power relationship between wife and husband. Another important aspect of domestic violence which is not at all reported is marital rape as well as other types of sexual abuse. A discussion with counselor working with abused women indicates that a very large percent of their clients were tortured by forced sexual intercourse against their will either with their husbands or any of their relatives. 


\section{Situation of Domestic Violence in Nepal}

Nepal is a patriarchal society. The women are still under the dark age of discrimination and the violence. Though the constitution has guaranteed the equality and also though the laws are being existed in regard to reduce domestic violence women $\mathrm{n}$ are still facing the problems. Violence against women in Nepal can be attributed to the cultural, religious, legislative and economic practices that conspire to keep women in a position of inferiority. Until women get essential opportunities in their daily lives in economic, social and political areas, they will not be able to take part in the decisionmaking process within the family as well as in the community because of the lopsided relationship between men and women. Most women do not even realize that they are being exploited, and this must change.

In Nepal domestic violence has been taken as a big challenge. To end such violence, different social institutions and the women human rights activists as well as the government itself is working. For the elimination of the domestic violence, domestic violence act, 2066 and domestic violence rules, 2067 have been introduced. Though there are such regulations, domestic violence is still in existence. There is different news regarding the domestic violence in the news papers and television day by day mostly inside the conjugal home. Such women who became the victim also aren't getting the proper justice. The reason behind is that due to the unclearness and the incomplete legal provisions (WOREK, 2069).

Historically, violence against women and girls (VAW\&G) has been in existence and a widespread in Nepali society but still unreported problem in Nepal. Data on the issue is hard to come by as there are very few studies done on the subject. Violence against women (VAW) has started being openly discussed and addressed only in the last decade. The lens of looking at women has changed significantly that shifted from being child bearers and providers of health care in the 60's and 70's to a slow realization of their critical productive role in rural economy in the 80 's, and to the recognition of women as citizens in need of equal legal and political rights in the 90's. Without comprehensive, carefully documented research on violence against women, it is impossible to know whether women are experiencing more violence in some countries than in others, or whether they are reporting it more often (Joshi and Kharel, 2008). One-third (35 percent) of women in Nepal experiences gender based violence at home, although most violence is unreported and unrecorded in informal or formal institutions. Psychological violence was found to be high, followed by physical, economic and sexual violence (Poudel, 2007).

Home is regarded as the most protective place but Nepalese women are unsafe in their home. They are being abused by their own close relatives. In such patriarchal society women are not free to express their pain and sorrow due to the fear of either fair, hesitation according to the report published by the WOREK Nepal. According to the report, among the total affected women from domestic violence, $67 \%$ are the literate woman, which clears that in Nepal the violence is not only with the illiterate woman but also to the literate woman. The literacy rate of woman is less than that of the men, which is also the 
responsible factor for the violence. The report also shows that the violence is more in the woman working in the agriculture and domestic sector rather than the woman working outside other than this. It shows that Nepalese woman are confined to the house hold works and they are violated inside their close relations. According to the report in Nepal there are physical violence, economic violence, mental violence and social violence in Nepal mostly found.

It is difficult for women, especially those who have been victims of gender based violence, to obtain justice because of various factors: discriminatory laws, slow legal processes, and the persistence of patriarchal ideologies. Men and women are still not equal in the eyes of Nepali legal institutions notwithstanding improvements in the relevant laws. Women feel that most of the men in legal agencies, political parties and civil society have negative attitudes concerning women who demand for their rights (UNDP, 2014). Violence against women and girls is one of the most prevalent human rights violations in the world. It knows no social, economic or national boundaries. Worldwide, an estimated one in three women will experience physical or sexual abuse in her lifetime (Baral, Uprety and Lamichhane, 2016).

In Nepal, social norms around masculinity, femininity, male guardianship of women and polygamy strongly shape men and women's behaviour and choices, and have a strong bearing on intimate partner violence. Men are accorded a superior social status and women's inferior status is largely unquestioned. Domestic violence is also generally accepted as a means of controlling women and/or correcting a wife or girlfriend's behavior (Ghimire and Samuels, 2017).

\section{Research Methods}

The descriptive and exploratory research designs have been adopted in the study. The case study research approach has been used. The sample is collected from Sheshnarayan Mahila Bidhyalaya, Pharping through the self administered questionnaire method. The interview has also been taken to the respondents. The research has been focused only in women respondents. The descriptive and analytical research tools have been used in the study. The research mainly focuses on violence at the husband's house. The SPSS version 20 has been used to analyze the information.

\section{Results}

Case of Sheshnarayan Mahila Bidhyalaya, Pharping

The school has been established specially for the women who are deprived of studying in their life in past. The purpose is to make woman at least capable of completing SEE/SLC or school level course. The questionnaire has been distributed to 25 women of the school, however only 13 become ready to response. The nature of domestic violence in women was found physical violence as most prone violence followed by economical violence, mental violence, social violence and others. 
Figure 1

Nature of Domestic Violence in Women of Pharping

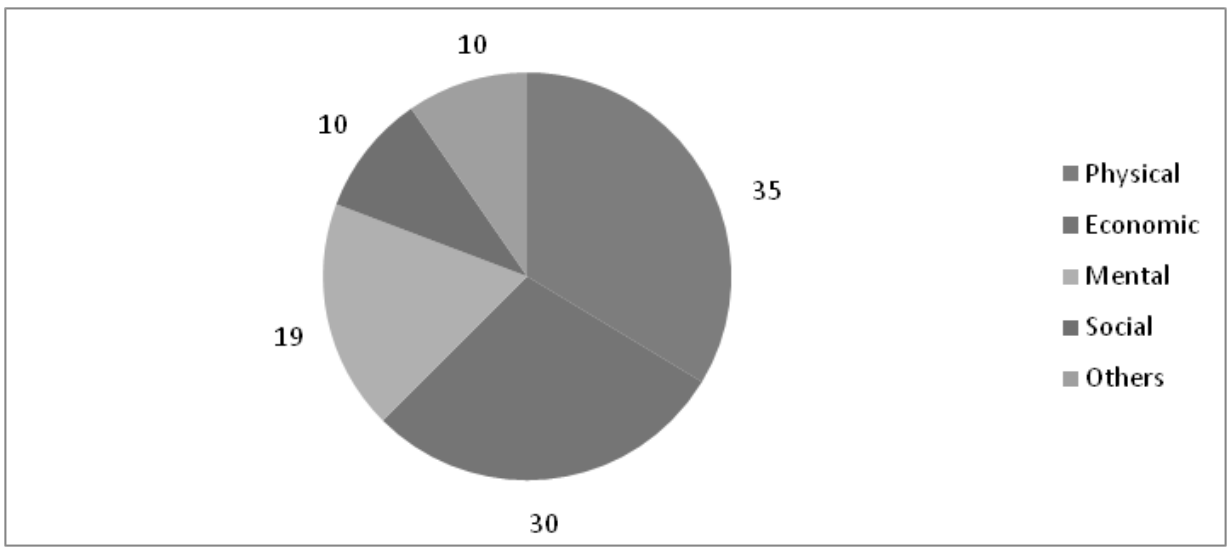

Though there are different laws regarding domestic violence in Nepal, day by day different violent news are being published in newspapers. Other news are also being heard like the death of women due to the husband's and other family member's torture.

The women were almost aware about the violence against woman. They had heard and seen such violence in their society and through the newspaper. They were aware that violence against woman could be of different forms like physical, mental and sexual. They had agreed that physical violence was not only the form of domestic violence. But the physical violence was mostly felt and seen in the society. It had included violence like slapping, beating, arm-twisting, stabbing, strangling, burning, choking, kicking, threats with a weapon and finally murder.

According to the respondents, it was found that women became victim of the violence inside their house. They were being tortured inside their house rather than outside. They were being tortured by their own close relatives. Then it also meant that woman working inside the house were more being violated rather than women working with other profession outside the home. The respondents were suffered from physical violence from their husband and other members in the family. One of the respondents was 16 years old and she was being beaten by her husband. The husband brought another wife and she was at her natal home. Another respondent was also beaten by her husband and the reason behind beating was her interest to study in women's school. The respondents had opined that to end such violent activity, first of all there must be awareness programs, woman themselves must be aware about the violence. They must be conscious first and the laws regarding it must be implemented in a proper manner. The literacy would become one of the most important aspects to end such violence.

Though Nepal is a party to convention on the elimination of all forms of discrimination against women and the constitution itself guarantees equality and protects woman from being suffered from any sort of violence and there is separate act for violence against 
woman, we can hear a lot of news about domestic violence daily. The situation of the woman, who is the victim of domestic violence, is very panic. They are victim in themselves and hatred by the society. In Nepal the woman from the remote areas are more victims of domestic violence. The girl is given tortured by the whole family. She would have no any option than to curse herself being born as a girl. The patriarchal society has made her to suppress herself and to face the problem without going to seek for the justice. The major problem is that the woman fear to express their problem so that most criminals are escaping from law. Likewise other forms of violence, domestic violence is not a problem of Nepal only, it is spread beyond the South Asian Regions and is prevalent in all parts of the world. However, due to lack of reporting of these kinds of matters in public, the criminals are escaping from the law.

\section{Conclusions}

In conclusion, there is a great need for the commitment of all people including social workers, organizations, and political institutions to bring the end to all forms of violence against woman. Having brought the criminal to the attention of the people, the authorities should be pressured to enforce strict legal measures. The strategy should be to raise awareness through formal and informal education. Preference should be given to the programs that develop gender awareness so that the negative attitude towards women can be changed. Such violence against woman could be mitigated.

\section{References}

Baral,S., Uprety, S., and Lamichhane, B.(2016).Gender Based Violence. Health Research and Social Development Forum, Kathmandu: Thapathali.

Ghimire, A., and Samuels, F. (2017). Understanding Intimate Partner Violence in Nepal. ODI and Nepal Institute for Social and Environmental Research, Lalitpur: Kushunti.

Hawkes, Et.,al.(2013). Tracking Cases of Gender Based Violence in Nepal: Individual, Institutional, Legal and Policy Analysis, CREHPA: UCL.

Joshi, S.K., and Kharel, J. (2008). Violence Against Women in Nepal: An Overview. Free Library.

Naya Patrika (2069). Mahila Mathi Hune Himsako Yetharthata. Lalitpur: Balkumari.

Poudel, G.S.(2007). Domestic Violence Against Women in Nepal. Gender Technology and Development, Vol. 11 (2), pp.199-233.

Pradhananga, R.B., and Shrestha, P.(2002). Domestic Violence against Women: Concept, History and Existing Laws. Annual Survey of Nepalese Law, 54.

Revathi, R.(2004). Law Relating to Domestic Violence. Hyderabad: Asia Law House. UNDP, (2014). Nepali Masculinities Gender Based Violence. UNDP, Kathamdnu: Nepal. UNICEF, (2001). A Reference Kit on Violence against Woman and Girls in South Asia. Kathmandu: Nepal. 


\section{Questionnaire}

Are you aware about the violence against woman?
(i) Yes
(ii) no
(iii) little bit yes

How do you understand about violence against woman specially focusing on domestic violence?
(i) Physical violence
(ii) emotional violence
(iii) sexual violence

(iv) Others

What sort of domestic violence have you seen?
(i) Physical violence
(ii) emotional violence
(iii) sexual violence

(iv) Others

Where have you seen woman being more victimized by violence?
(i) Inside home
(ii) at work place
(iii) in society

(iv) other places

Have you become the victim of domestic violence?
(i) Yes
(ii) No

If you have become victim, where you have suffered?
(i) Inside home
(ii) at work place
(iii) in society

(iv) other places

What sort of violence you have been suffering?

(i) Physical (ii) emotional (iii) sexual (iv) all

To reduce such violence in Nepal, what measures, should be taken? Give your view. 